
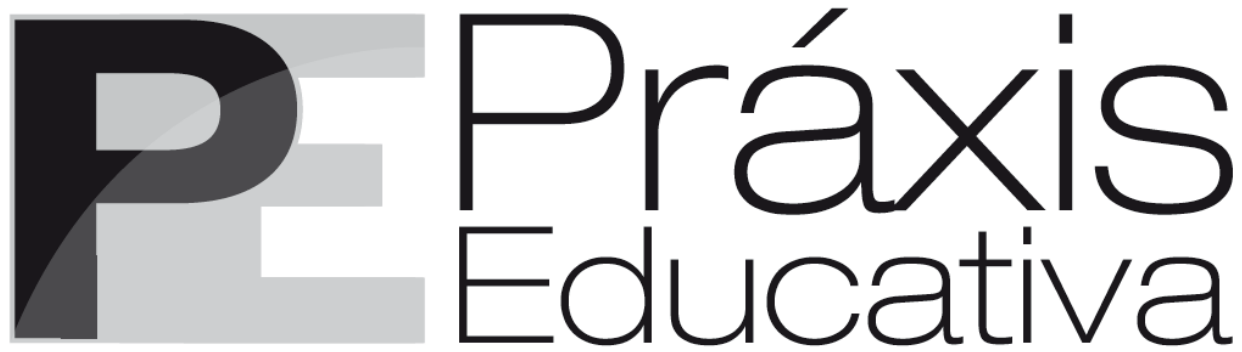

ISSN 1809-4309 (Versão online) DOI: 10.5212/PraxEduc.v.12i3.011

\title{
Domínios e elementos da profissionalidade docente nas representações sociais de professores de Matemática
}

\author{
Skills and features of professionalism through Maths teachers' social \\ representations
}

\section{Dominios y elementos de la profesionalidad docente en las representaciones sociales de profesores de Matemáticas}

Elisângela Bastos de Melo Espindola* Lícia de Souza Leão Maia**

\begin{abstract}
Resumo: Este trabalho, fruto de uma tese de doutorado, tem por objetivo analisar as representações sociais de professores de matemática brasileiros e franceses acerca de sua competência profissional. A análise está ancorada em um levantamento teórico sobre a relação entre os termos profissão e profissionalidade e sobre elementos e domínios da profissionalidade docente (ABAELLA, 1992; ROLDÃO, 2005, entre outros). A metodologia fundamenta-se na Teoria do Núcleo Central (ABRIC, 1976). A pesquisa contou com a participação de 252 professores de matemática brasileiros e franceses atuantes em escolas públicas. Dentre os resultados, destacamos as semelhanças e diferenças entre as representações dos professores sobre sua competência profissional, baseadas nos domínios deontológico, disciplinar, didático, pessoalidade, entre outros, da profissionalidade docente.
\end{abstract}

Palavras-chave: Profisssionalidade docente. Representações Sociais. Competência Profissional de Professores de Matemática.

\begin{abstract}
This study, originated from a $\mathrm{PhD}$ thesis and aims at analyzing Brazilian and French Maths teachers' social representations of their professional competence. The analysis is based on a theoretical survey of the relation between the terms profession and professionalism and elements related to the skills and features of teachers' professionalism (ABAELLA, 1992; ROLDÃO, 2005, among others). The methodology is based on the Central Nucleus Approach (ABRIC, 1976). The research comprised 252 Brazilian and French teachers of Mathematics working in public schools. Among the results, we highlight the similarities and differences between teachers' representations of their professional competence, based on the domains of ethics, subject taught, teaching methods, personality, among others, of the teacher professionalism.
\end{abstract}

Keywords: Profissionalism. Teacher. Social Representations. Maths teachers' professional competence.

\footnotetext{
* Professora adjunta do Departamento de Educação da Universidade Federal Rural de Pernambuco. E-mail: <ebmespindola@gmail.com>.

** Professora titular do Centro de Educação da Universidade Federal de Pernambuco. E-mail: <limaia@ufpe.br>.
} 
Resumen: Este trabajo, resultado de una tesis doctoral, objetiva analizar las representaciones sociales de profesores de matemáticas brasileños y franceses acerca de su competencia profesional. El análisis se fundamenta en un levantamiento teórico sobre la relación entre los términos profesión y profesionalidad y sobre elementos y dominios de la profesionalidad docente (ABAELLA, 1992, ROLDÃO, 2005, entre otros). La metodología parte de la Teoría del Núcleo Central (ABRIC, 1976). La investigación contó con la participación de 252 profesores de matemáticas brasileños y franceses actuantes en escuelas públicas. Entre los resultados, destacamos las similitudes y diferencias entre las representaciones de los profesores sobre su competencia profesional, asentadas en los ámbitos deontológico, disciplinario, didáctico, personalidad, entre otros, de la profesionalidad docente.

Palabras clave: Profesionalidad docente. Representaciones Sociales. Competencia Profesional de Profesores de Matemáticas.

\section{Introdução}

Para a análise da profissionalidade docente à luz das representações sociais de professores de matemática brasileiros e franceses acerca de sua competência profissional docente, apresentamos, de início, um levantamento teórico sobre as abordagens sociológicas (funcionalista, interacionista, neoweberiana e neomarxista) que discutem a noção de profissão, articulando-o com a noção de profissionalidade.

A explicitação dos procedimentos metodológicos está assentada na Teoria do Núcleo Central (ABRIC, 1976), que tem, como um dos seus pressupostos, a identificação da organização interna das representações sociais; ou seja, o seu sistema central e o periférico.

Dentre os aspectos que esta pesquisa revela, destacamos as aproximações e distanciamentos entre as representações dos professores de matemática brasileiros e franceses acerca de sua competência profissional docente, em diálogo com os domínios e elementos da profissionalidade docente: Sistema Educativo, Formação Profissional, Pedagógico, Disciplinar, Deontológico, entre outros - extraídos a partir de componentes e descritores indicados, por autores, a exemplo de Roldão (2005), Contreras (2002) e Demailly (1992).

\section{Profissão e profissionalidade}

De acordo com Dadoy (1986), a noção de profissionalidade veicula explicitamente uma conotação fortemente positiva, em razão de sua referência à noção de "profissão" (alto nível de conhecimento, saberes bem especializados, técnica elaborada...) e de profissionalização (ofício/profissão, domínio do processo de trabalho...). Para Braem e Aballea (2002), a profissionalidade é o alicerce da profissão; na medida em que não existe profissão sem profissionalidade. Porém, à luz das teorias sociológicas das profissões anglo-saxãs, a profissionalidade não parece ser suficiente para definir uma "profissão", pois, considera-se que falar de profissionalidade é, de certo modo, pôr em evidência os processos de desprofissionalização e profissionalização dos ofícios. Ou mesmo, pode-se dizer que falar de profissionalidade põe em causa pretensões "profissionais".

Sobre a profissionalização dos ofícios ao status de "profissão", quatro abordagens sociológicas são, notadamente, reconhecidas na literatura: funcionalista; interacionista, neomarxista e neoweberiana. A abordagem funcionalista tem sido definida como atributiva e normativa devido ao seu conjunto de proposições sobre o comportamento social dos profissionais; "de seu conjunto de características, critérios ou pré-requisitos em que se deve 
enquadrar uma atividade ocupacional que pretenda atingir a categoria de profissão" (RAMALHO, et al., 2004). Contudo, é inegável a contribuição da abordagem funcionalista ao entendimento de questões como: o que é uma profissão? Qual a sua função social? Quais os atributos que possuem? Em que termos se distinguem das ocupações comuns? Em torno destas questões, apresentamos algumas considerações sobre as obras clássicas dos autores: Durkheim (1984); Flexner (1915); Carr-Saunders e Wilson (1933); Parsons (1958); Goode (1957) e Wilensky (1964).

Segundo Durkheim (1984), a atividade de uma profissão não pode ser regulamentada eficazmente, senão por um grupo bastante próximo desta mesma profissão, o suficiente para conhecer-lhe bem o funcionamento, para sentir-lhe todas as necessidades e poder seguir todas as suas variações. A corporação seria o meio natural no seio do qual devem se elaborar a moral e o direito profissionais. Assim "onde quer que se forme um grupo, forma-se também uma disciplina moral". De acordo com Flexner (1915) citado por Dubar e Tripier, os critérios que fazem com que um ofício seja considerado como profissão são:

1. As profissões tratam de operações intelectuais associadas a grandes responsabilidades individuais; 2. Os materiais de base são tirados da Ciência e de um saber teórico; 3. que comportam aplicações práticas e úteis; 4. e são transmissíveis por um ensino formalizado; 5. As profissões tendem à autoorganização em associações; 6.e seus membros tem uma motivação altruísta (DUBAR; TRIPIER, 2010, p. 3).

Estes critérios se apresentam como precursores dos trabalhos na Inglaterra de Carr Saunders e Wilson, autores da definição clássica ${ }^{1}$ segundo a qual "uma profissão emerge quando um número definido de pessoas começa a praticar uma técnica definida e fundada sobre uma formação especializada" (BLIN, 1997, p. 50). A partir de:

1. Especialização dos serviços, permitindo aumentar a satisfação de uma clientela; 2 . Criação de associações profissionais, [...] "colocando uma linha de demarcação entre eles e as pessoas não qualificadas", o que permitia aumentar o prestígio do "ofício" [...], principalmente definindo e controlando as regras de conduta profissionais ainda não qualificadas de "código de ética e de deontologia profissionais"; 3. Implantação de uma formação especializada fundamentada em "um corpo sistemático de teoria" permitindo a aquisição de uma cultura profissional (DUBAR, 2005, p. 171).

Dubar (2005) coloca que para Parsons ${ }^{2}$ a institucionalização dos papéis nas " profissões » resulta de um equilíbrio das motivações entre a necessidade que o cliente tem do profissional e a necessidade do profissional de ter clientes. Baseado em:

1. Um saber prático ou "ciência aplicada" que articula uma dupla competência: a que é fundamentada num saber teórico adquirido no decorrer de uma formação prolongada e sancionada e a que se apoia na prática, na experiência de uma "relação benevolente"... 2. Uma competência especializada ou "especificidade funcional", que se apresenta como uma dupla capacidade: a que repousa na especialização técnica da competência e que limita a autoridade do "profissional" unicamente à área legítima de sua atividade, e a que funda seu poder social de prescrição e de diagnóstico em uma "relação mais ou menos recíproca"; 3. Um interesse imparcial, característica da dupla atitude do "profissional", que alia a norma da neutralidade afetiva ao valor de orientação para o outro, de interesse empático pelo cliente e por sua expectativa incondicional (DUBAR, 2005, p. 172-173).

\footnotetext{
${ }^{1} \mathrm{Na}$ obra "The Professions", 1933.

2 Ver Parson (1958).
} 
Assim, percebe-se a «profissão » como campo de aplicação da Ciência. Por exemplo, o médico é portador da competência técnica, juridicamente garantida, para resolver o problema da doença. Destarte, sublinha-se a confiança do cliente no saber do profissional. $\mathrm{Na}$ visão de Goode $^{3}$, um dos principais discípulos de Parsons, o que categoriza toda profissão é o fato de ela ser uma comunidade, e é esta a aspiração de toda ocupação que pretende se profissionalizar.

\begin{abstract}
1. Seus membros estão ligados por um sentido de identidade; 2 . Uma vez nela, poucos a deixam, de modo que é um status para a maioria; 3. Seus membros partilham valores comuns; 4. As definições de papéis de membros e não-membros são objeto de acordo e são as mesmas para todos os membros; 5 . Nas áreas de ação comum há uma linguagem comum, que é compreendida apenas parcialmente pelos de fora; 6 . A comunidade tem poder sobre seus membros; 7. Seus limites são razoavelmente claros, apesar de serem sociais e não físicos ou geográficos; 8. Apesar de não produzir a próxima geração biologicamente, ela o faz socialmente pelo controle sobre a seleção de professores e pelos processos de treinamento ela socializa seus recrutas (BARBOSA, 1993, p. 14).
\end{abstract}

Champy (2009, p. 49) destaca que na abordagem funcionalista de Goode: "a comunidade profissional é mais exigente que a lei quanto ao comportamento de seus membros". Por fim, na abordagem de Wilensky, para ser reconhecida como profissão, uma ocupação deve adquirir sucessivamente seis características: "1. Exercer a profissão como atividade principal, 2. Comportar as regras da atividade, 3. Obter uma formação especializada, 4. Possuir organizações profissionais, 5. Comportar uma proteção legal de monopólio e 6 . Ter estabelecido um código de deontologia" (DUBAR; TRIPIER, 2010, p. 90).

Pelo exposto, podemos dizer que algumas das consequências da abordagem funcionalista sobre a docência é sua adjetivação como "semiprofissão", pela adequação imperfeita ao modelo anglo-saxão, baseado nas profissões liberais (Medicina, Direito...). Por exemplo, Contreras (2002) considera que falta aos professores: autonomia com relação ao Estado que fixa sua prática, carência de um conhecimento próprio especializado e de uma organização exclusiva que regule o acesso e o código profissional. Sacristán (1999, p. 71) discute que a profissão docente é uma semiprofissão, "em parte porque depende de coordenadas político-administrativas que regulam o sistema educativo em geral, e as condições do posto de trabalho, em particular". Para este autor, "a própria profissão foi ganhando forma à medida que ia nascendo a organização burocrática dos sistemas escolares e, por isso, é lógico que a sua própria essência reflita as condições do meio em que se molda". Veiga (2006) propõe uma lista de aspectos condicionantes de desprofissionalização do magistério: a feminização e a baixa origem social; a burocratização, as condições e o aumento da carga horária de trabalho dos professores (intensificação); o isolamento, o personalismo e o individualismo, com que os docentes entendem a autonomia de trabalho; a carreira e a remuneração; a ausência de sistematização deontológica, etc.

Grosso modo, convém salientar, sobre a abordagem funcionalista, algumas críticas. Uma delas diz respeito à enumeração dos atributos de características "essenciais" e universais que atribuem ou negam o status de profissão às ocupações, baseando-se na experiência particular de nações desenvolvidas como os Estados Unidos ou Inglaterra, como se a natureza das profissões (Medicina, Direito, Engenharia), aí encontradas, fosse típica em todos os países, como modelos a serem perseguidos. Assim, uma outra perspectiva sociológica sobre as profissões, ainda que sua origem seja anglo-saxã, diz respeito à abordagem interacionista. Esta apareceu nos anos 50, no interior da Escola de Chicago, e sua influência se difundiu em diversos países, a exemplo da França, quando a sociologia das profissões começou a chegar neste país, nos anos 80 . O que de certa forma influenciou estudos baseados na sociologia dos grupos profissionais, em detrimento da sociologia das profissões (centrada nas profissões liberais). Sobre este fato, Demazière e

${ }^{3}$ Ver Goode (1957).

Práxis Educativa, Ponta Grossa, v. 12, n. 3, p. 887-908, set./dez. 2017 Disponível em: <http://www.revistas2.uepg.br/index.php/praxiseducativa> 
Gadéa (2009, p.20) descrevem duas consequências: a primeira concerne à extensão do domínio de estudo aos inúmeros ofícios e atividades (não só apenas às profissões liberais: Medicina, Direito e Engenharia) e a segunda, conduz a "olhar os grupos profissionais não como grupos protegidos, fechados ou codificados, mas como processos evolutivos, vulneráveis, abertos, instáveis".

Ao contrário das questões centrais dos funcionalistas: quais ocupações são ou não profissão? (ou é ou não é). As questões dos sociólogos interacionistas são voltadas para: como os ofícios são considerados profissões? Que critérios orientam a distinção, na vida social, entre profissões e outros ofícios? Como o estudo dos «pequenos ofícios» podem nos ajudar a correlacionar o folk concept de profissão à renovação do olhar que nós temos sobre os ofícios que adquiriram o status de profissão? (CHAMPY, 2009). Para exemplificar esse posicionamento, destacamos as proposições básicas dos autores interacionistas Hugles, Bucher, Strauss e Becker.

Hugles ${ }^{4}$ desenvolveu os conceitos de licença e mandato. Para este autor, todo emprego (ocupação) reivindica ser autorizado (ter licença) a exercer certas atividades que outros não poderão exercer, a assegurar uma certa segurança do emprego, limitando a concorrência. Todo coletivo que exerce uma atividade (ocupação) é conduzido a "estabilizar seu domínio, seu território, sua definição obtendo de seus pares (e notadamente daqueles que tem o poder) uma autorização específica, limitando a concorrência, e uma missão reconhecida, valorizando o grupo" (DUBAR; TRIPIER, 2010, p. 98).

Atribuem-se a Bucher e Strauss, ${ }^{5}$ na década de 60, as noções de "segmento" e de "ordem negociada" ligadas às configurações dos atores e à organização das tarefas. O termo " segmento » é utilizado para designar os agrupamentos que emergem no interior das profissões. Ou seja, os diferentes segmentos de uma profissão são levados a entrar num processo de ajustamento em relação ao cotidiano de trabalho, definindo uma ordem negociada. Por exemplo, em um hospital, a ordem social "não advém somente do regulamento e dos estatutos, mas também dos ajustamentos entre os profissionais e os outros. Os médicos, os enfermeiros, mas também o pessoal administrativo, técnico, os doentes e suas famílias intervêm na regulação da atividade" (idem). No campo da docência, Tardif et al. (1998) exemplifica que o sistema educacional é composto de diversos segmentos: os práticos, que seriam os professores e outros situados na administração escolar, na administração mais geral (Ministério da Educação), nas universidades, entre outros. A distinção dos segmentos, entre si, ocorre por uma construção comum de situações e de crenças partilhadas sobre as atribuições e o sentido subjetivo da atividade profissional.

Credita-se a Becker a acepção de "profissão" como folk-concept - "um conceito popular multifacetado, intrinsecamente ambíguo, do qual nenhuma definição única e nenhuma tentativa de isolar sua essência poderão ser amplamente persuasivas" (FREIDSON, 1998, p. 59). Neste sentido, concordamos com Lucas (1994, p. 20) sobre o fato de que a abordagem interacionista teve um papel primordial no estudo dos grupos profissionais, constituídos como "processos dinâmicos, tendo uma história e apresentando variações e diversidades segundo, notadamente, os campos profissionais - as condições sociais de emergência, os modos de construção, de legitimação e eventualmente de institucionalização". Assim, nesta perspectiva de caráter mais processual, tem ecoado pesquisas sobre o processo sócio-histórico em que se foi moldando a profissão docente, na busca de se levar em conta o processo de conquistas dos professores a

\footnotetext{
4 Ver Hughes (1958).

5 Ver Bucher e Strauss (1992).

${ }^{6}$ Ver Becker (1988).
} 
Domínios e elementos da profissionalidade docente nas representações sociais de professores...

partir de diferentes contextos sociais, econômicos, políticos, etc. Por exemplo, no caso português, Nóvoa (1999) apresenta no processo de profissionalização do professorado: quatro etapas (exercício a tempo inteiro; estabelecimento de um suporte legal para o exercício da atividade docente; criação de instituições específicas para a formação de professores; constituição de associações profissionais de professores); duas dimensões (um corpo de saberes e técnicas e um conjunto de normas e de valores específicos da profissão docente) e um eixo estruturante (estatuto social e econômico dos professores).

Por fim, posteriormente às proposições interacionistas, temos a emergência de novas conceptualizações de natureza heterogênea sobre as "profissões". Por exemplo, Freidson conjuga contributos do interacionismo com a abordagem neoweberiana para análise do poder profissional. Larson discute esta questão por meio do neomarxismo. Dentre as proposições neoweberianas fundamentais ao estudo das "profissões", destacam-se aquelas que concebem os grupos profissionais como formas de poder político nas sociedades modernas e que o suporte da proteção do Estado poderia estabelecer o monopólio em bases legais, fazendo das profissões "grupos legalmente privilegiados". Outro aspecto concerne à figura do expert (com incomparável superioridade técnica na garantia de precisão, velocidade, clareza, redução do atrito dos custos de material e pessoal, etc.) dentro de uma lógica de legitimidade legal-racional, importada da administração, da burocracia. Manifesta-se a valorização do trabalho abstrato; ou seja, a racionalização do trabalho intelectual, como efeito das mudanças pelas quais passou a sociedade moderna; cujo capitalismo competitivo cria condições de mercado, influenciando, mudanças institucionais, jurídicas ou culturais exteriores às profissões. Por exemplo, apresentamos como Freidson, Larsons e Abbott teorizam sobre o "poder" e o "saber" profissionais, ou seja, a dimensão cognitiva como legitimação dos grupos profissionais e monopólio de sua atividade.

Para Freidson (1998, p. 40), o "que distingue as ocupações umas das outras é o conhecimento e competência especializados necessários para a realização de tarefas diferentes numa divisão do trabalho". A autonomia profissional "requer a capacidade de uma profissão controlar uma área do conhecimento, tendo o monopólio sobre o campo, sem depender de outras profissões para a sua prática rotineira". O alto nível de competência que detém o profissional interdita a outros de portar um julgamento sobre sua prática.

Segundo Barbosa (1993, p. 11), para Larsons "os diferentes tipos de saber produzem diferenças entre as profissões, pois o tipo de conhecimento que cada profissão detém, determina possibilidades diferenciais no processo de unificação do campo profissional e no uso dos recursos organizacionais". A presença marxista na obra de Larson pode ser observada sob "o movimento de racionalização apresentado como um simples "instrumento ideológico" do capital e não como um processo social de conquista coletiva" (DUBAR; TRIPIER, 2010, p. 132). Para Almeida (2010, p. 123-124), as proposições de Larson cedem lugar às reflexões neomarxistas quando articulam os mecanismos de reprodução econômica àqueles de reprodução social e na medida em que "a profissionalização surge como um projeto de mobilidade coletiva com vistas a atingir ou preservar, quer novas posições econômicas quer novas posições ao nível do estatuto e do prestígio social". Nesta abordagem, a profissão conta com uma base cognitiva bem desenvolvida, estabelecida e validada; isto é, uma base cognitiva que independe do locus da sua utilização, dificilmente o profissional é exposto aos riscos da racionalização do trabalho.

De outro ponto de vista, Abbott (1988) discute que as relações de trabalho envolvem as tarefas e as pessoas que executam essas tarefas e essas relações sofrem constantes mudanças. Essas mudanças são influenciadas por fatores que vão além das profissões, ou seja, a tecnologia, a política e outras forças sociais que dividem e refazem os grupos. Neste sentido, a legitimação do saber, por um grupo profissional específico é posta em destaque, reconhecendo que "a habilidade

Práxis Educativa, Ponta Grossa, v. 12, n. 3, p. 887-908, set./dez. 2017 Disponível em: <http://www.revistas2.uepg.br/index.php/praxiseducativa> 
de uma profissão sustentar sua jurisdição encontra-se parcialmente no poder e prestígio de seu conhecimento acadêmico" (ABBOTT, 1988, p. 53).

Abbott discute que para "conseguir controlar um território de ação, uma profissão deve procurar aliados, não somente no Estado ou na população que constitui seu mercado potencial, mas junto a outras profissões" (DUBAR; TRIPIER, 2010, p. 132). Abbott (1988) vê na eficácia das soluções que as profissões propõem aos problemas que têm que resolver um fator determinante na delimitação de territórios. Assim, no enfraquecimento de algumas profissões, outras aproveitam estas ocasiões para reforçar suas jurisdições. Sendo estas, tentativas de controle legítimo sobre reivindicações profissionais.

Não obstante das contribuições das diversas abordagens sociológicas sobre as profissões podemos situar a profissionalização de ofícios, ou do caso mais específico da docência, como uma demanda do próprio grupo profissional, definir e estabelecer coletivamente que patamar na esfera social deseja ocupar e pensar sobre os meios que podem fazer sua atividade evoluir. Neste sentido, estamos de acordo com Ramalho et al. (2004) no sentido de que este tipo de profissionalização (dos ofícios) acarreta um processo de "negação dialética", "que implica negar os modelos da sociologia clássica, e ao mesmo tempo considerar deles os elementos que possam, por sua vez, orientar a busca de uma identidade docente". Como afirma Aballea (1992), constituir uma profissão não é um fim em si mesmo. No entanto, definir uma profissionalidade original, logo, uma expertise específica e uma deontologia ou, mais globalmente, um sistema de referências próprias, garantindo a eficácia e a finalidade social de uma atividade profissional pode constituir, sem dúvida, longe das reinvindicações corporativistas, uma ambição legítima. Desta forma, a noção de profissionalidade tem sido discutida, a depender do autor, a partir de diversos componentes, descritores, sistemas, indicadores, etc., que, de certa forma, retomam o que apresentamos sobre os aspectos tratados nas teorias sociológicas clássicas das profissões ou dos grupos profissionais.

\section{Elementos e domínios da profissionalidade docente}

A origem da noção profissionalidade ocorreu na Itália. Segundo Massip (2000), até 1960, esta concernia à capacidade profissional do trabalhador, ou às capacidades profissionais adquiridas por este, tendo como pano de fundo "o ofício", definido a partir dos conhecimentos e do saber-fazer baseado em práticas de referência. De acordo com Barisi (1982), até 1960 a "profissionalidade" era compreendida como um meio de preservar os saberes e o saber fazer dos ofícios ditos "tradicionais", tendendo "naturalmente" a desaparecer em virtude da introdução da mecanização e do taylorismo.

Para Massip (2000), numa segunda etapa (de 1960 a 1968), a profissionalidade dizia respeito às capacidades pessoais de adaptação do indivíduo, autonomia e polivalência. Neste contexto, a noção de "professionalità" reivindicada pelos sindicatos não se referia somente à experiência profissional, ao passado do trabalhador, ela fazia antecipações sobre o futuro deste e reivindicava, por exemplo, o direito à formação. Convém salientar que de 1960 a 1968, diversos sistemas de avaliação da qualificação do trabalhador apareceram na Itália. Ou seja, a classificação da mão de obra do trabalhador estava obrigatoriamente relacionada à divisão do trabalho operada por órgãos de controle, não sendo, necessariamente, correspondente ao nivel real de qualificação dos trabalhadores (sua professionnalitâ). Percebiam-se, nas categorizações hierárquicas, certos descompassos entre estas e o nível das capacidades e conhecimentos profissionais dos trabalhadores. Neste contexto de desestabilização e de tentativa de correlacionar cada trabalhador às exigências de seu posto de trabalho, desenvolveram-se prerrogativas de polivalência e mobilidade, mas também de valorização da disponibilidade e adaptabilidade dos trabalhadores;

Práxis Educativa, Ponta Grossa, v. 12, n. 3, p. 887-908, set./dez. 2017 Disponível em: <http://www.revistas2.uepg.br/index.php/praxiseducativa > 
Domínios e elementos da profissionalidade docente nas representações sociais de professores...

diz-se mesmo das "características individuais". Não necessariamente, relacionadas às capacidades profissionais adquiridas pela formação profissional ou pela experiência na "fábrica", mas um tipo de apelo, em parte, à personalidade de cada um.

Massip (2000) aponta que numa terceira etapa, a professionalità levava em conta a característica e a potencialidade do grupo homogêneo; consequentemente, a capacidade profissional coletiva e a valorização de seus membros. Assim, se, até 1968, tínhamos o uso do termo profissionalidade voltado para a defesa dos trabalhadores face à desqualificação, em virtude do desaparecimento de ofícios tradicionais e também da adaptação aos novos critérios de classificação e formas de organização do trabalho, nos anos de 1968 até 1974 são marcados por uma ação sindical mais ofensiva, desenvolvendo-se sobre a noção de profissionalidade uma conotação coletiva e igualitária entre os trabalhadores. As conquistas sindicais em nome do coletivo dos trabalhadores desenvolveu o sentido à professionnalitá de "potencialidade profissional coletiva”. Segundo Barisi (1982), a partir dos anos de 1974, a emergência do uso da palavra professionnalità na Itália teve um retorno às características de subjetividade em referência à capacidade profissional dos trabalhadores (característica dos anos 60). Contudo, com uma diferença: enquanto nos anos 60, a profissionalidade era definida como capacidade profissional expressa no trabalho e que, portanto, estava em relação direta com as tarefas efetuadas; por volta do fim dos anos 70, a noção de professionnalità chegou a manter em algumas empresas as conotações de caráter coletivo, ligadas aos resultados do trabalho e ao nível de eficácia que dela poderia fazer emergir. Assim, na Itália, a profissionalidade expressou ao longo do tempo:

Opor a capacidade profissional do trabalhador à lógica técnico-organizacional do patronato; exigir um nível de classificação mais elevado e reduzir o leque hierárquico das remunerações; obrigar de modo permanente os empregadores a modificar sua política de organização das condições de trabalho para o percebimento da evolução das capacidades profissionais; manter unificada e solidária toda a classe operária; criar uma solidariedade técnica entre os operários (MASSIP, 2000, p. 25).

No contexto da docência, Ambrosetti e Almeida (2007) apontam que: "investigar o trabalho docente na perspectiva da profissionalidade implica compreender os professores como atores sociais que, agindo num espaço institucional dado, constroem nessa atividade, sua vida e sua profissão". Compreende-se que "a constituição da profissionalidade docente está intimamente ligada às experiências pessoais e profissionais e essas trajetórias são marcadas pelo contexto social e pelas relações de trabalho". D'avilla (2010, p. 2) explica a profissionalidade "como um conjunto de saberes, habilidades e valores constituintes do que há de específico em uma dada profissão".

De acordo com Cruz e Neto (2012), a análise da profissionalidade a partir dos elementos estruturantes (saberes, comportamentos...) nos permitiria afirmar que sua construção se dá numa dinâmica de interação entre os elementos de regulação social da profissão e as formas subjetivas do sujeito que se faz professor. Segundo Sacristán (1999, p. 74), a essência da profissionalidade docente reside na relação dialética entre tudo o que, através do professor, pode-se difundir conhecimentos, destrezas profissionais, etc. - e os diferentes contextos práticos. Neste sentido, "é preciso ampliar o sentido e conteúdo da profissionalidade docente, isto é, o âmbito dos temas, problemas, espaços e contextos em que o professor deve pensar e intervir". Roldão (2005, p. 109) descreve a profissionalidade como "aquele conjunto de atributos, socialmente construídos, que permitem distinguir uma profissão de outros muitos tipos de atividades, igualmente relevantes e valiosas". A partir dos caracterizadores ou descritores:

$\mathrm{O}$ reconhecimento social da especificidade da função associada à atividade. $\mathrm{O}$ saber específico indispensável ao desenvolvimento da atividade e sua natureza. O poder de decisão sobre a ação desenvolvida e consequente responsabilização social e pública pela

Práxis Educativa, Ponta Grossa, v. 12, n. 3, p. 887-908, set./dez. 2017 Disponível em: <http://www.revistas2.uepg.br/index.php/praxiseducativa> 
mesma - dito doutro modo, o controle sobre a atividade e a autonomia do seu exercício; e a pertença a um corpo coletivo, que partilha, regula e defende intramuros desse coletivo, quer o exercício da função e o acesso a ela, quer a definição do saber necessário, quer naturalmente o seu poder sobre a mesma que lhe advém essencialmente do reconhecimento de um saber que o legitima (ROLDÃO, 2005, p. 109).

Sobre a especificidade da função, Roldão (2005) explica que se trata da natureza específica do que se faz - e a respectiva utilidade social - e sobre o saber específico, o domínio de um saber próprio que outros não dominam. O poder de decisão concerne a responder por suas ações perante os utilizadores de seus serviços e, sobre o coletivo, o sentimento de pertença comum entre outros aspectos na defesa de prestígio e exclusividade de seu saber. Popkewitz (1996) citado por Sacristán (1999, p. 65), considera que "o conceito de profissionalidade docente, está em permanente elaboração, devendo ser analisado em função do momento histórico e da realidade social que o conhecimento escolar pretende legitimar; em suma, tem de ser contextualizado". Assim sendo, ele propõe levar em conta o contexto pedagógico, profissional e social. Bazzo (2007) acrescenta a estes, o contexto político:

O contexto pedagógico: caracterizado pelas práticas pedagógicas cotidianas que derivam do ensinar como, as rotinas da classe, os procedimentos de ensino, os processos de avaliação, o material escolar, etc. O contexto profissional: que molda em grande medida o comportamento profissional a partir de ideologias, crenças, rotinas e normas de comportamento social. O contexto social: de onde emanam os valores e ideologias que tendem a ser incorporadas pelos profissionais [...]. E mais ainda, segundo o contexto político: que se refere às determinações das políticas públicas, as legislações e seus efeitos (BAZZO, 2007, p. 93).

Para Demailly (1992), é interessante identificar os componentes da profissionalidade docente, tal como os dispositivos de formação são levados a formalizá-los:

Competência ética - não é possível contestar o papel essencial da orientação ética e sociopolítica do professor na produção da prestação de serviço. Saberes científicos e críticos - sistematizados em disciplinas científicas, cujas fronteiras históricas não são estáveis e, a partir da sua difusão no seio da escola, podem ser transformados e sedimentados em disciplinas escolares, isto é, em objetos de ensino. Saberes didáticos relacionados à transmissão e aquisição de um domínio do saber escolar. Competências dramáticas e relacionais - trata-se de competências corporais, comportamentais: saber movimentar-se, colocar a voz; estar atento a tudo que se passa, dominar a agressividade, improvisar, etc. Saberes e saber-fazer pedagógicos - relacionados à questão do trabalho em grupo na sala de aula: organização espaço-temporal...Conhecimento das características dos diversos tipos de grupos e capacidade para as operacionalizar. Meios de ensino [...]. As tecnologias e as metodologias. Competências organizacionais relacionadas com as metodologias do trabalho coletivo, de organização de um grupo profissional local; de estímulo à comunicação interna e externa, de incentivo às suas relações com o meio (DEMAILLY, 1992, p. 153-154).

Para Contreras (2002, p. 74), "falar de profissionalidade significa não só descrever o desempenho do ofício de ensinar, mas também expressar valores e pretensões desejáveis de alcançar e desenvolver na profissão". A profissionalidade é apresentada em três dimensões:

A obrigação moral - deriva do fato de que o ensino supõe um compromisso de caráter moral para quem a realiza. O compromisso com a comunidade - deriva da relação com a comunidade social na qual os professores devem realizar sua prática profissional. A competência profissional - a realização do ensino necessita, como qualquer outro trabalho, de um certo domínio de habilidades, técnicas e, em geral, recursos para a ação didática, da mesma forma que deve conhecer aqueles aspectos da cultura e do conhecimento que constituem o âmbito ou o objeto do que se ensina (CONTRERAS, 2002, p. 76-82).

Práxis Educativa, Ponta Grossa, v. 12, n. 3, p. 887-908, set./dez. 2017 Disponível em: <http://www.revistas2.uepg.br/index.php/praxiseducativa> 
Sarramona (1995) propõe como características definidoras da profissionalidade: 1. Delimitação de um âmbito específico de atuação. 2. Preparação técnica e científica para resolver os problemas próprios de seu âmbito de atuação. 3. Compromisso de atualização e aperfeiçoamento dos conhecimentos e habilidades que lhes são próprios. 4. Um certo direito social como indivíduo e como coletivo profissional. 5. Autonomia na atuação. 6. Compromisso deontológico com a prática docente. Para Melyani (1995) a profissionalidade trata-se de um processo de melhoria das capacidades e da racionalização dos saberes postos em prática no exercício da profissão, em vista de uma maior eficácia individual e coletiva a partir de:

\begin{abstract}
Um sistema de expertise - por definição uma expertise «intelectual», de caráter « abstrato » e composto. Baseada nos eixos do saber, do saber-fazer e do saber ser. Um sistema de referências e valores - normas próprias aos professores, que constituem o universo «moral » deste grupo profissional [...], em torno do bem-estar do aluno (e das gerações futuras) e não em torno da busca do proveito e da satisfação pessoal. Um sistema de formação. Uma formação universitária longa e mais frequentemente, de natureza científica constitui uma dimensão essencial na definição de uma profissão (MELYANI, 1995, p.531-533).
\end{abstract}

Aballea (1992) e Braem (2000) destacam como condições, especificamente, constituintes da profissionalidade: 1. A delimitação de um objeto (relacionado ao domínio e a finalidade de intervenção da profissão), 2. A existência de um saber (um sistema de expertise); 3. Por em prática este saber (a utilização deste saber segundo um sistema de normas e valores). Bancel (1989) indica três polos de conhecimentos que delimitam os contornos de uma profissionalidade, aqueles relativos à: identidades disciplinares (saberes a ensinar; história, epistemologia e relações sociais das diferentes disciplinas); gestão da aprendizagem (didáticos e pedagógicos) e ao sistema educativo (política educativa nacional, estrutura e funcionamento da instituição, etc.). Nóvoa (2009) chama a atenção para a relação entre a pessoalidade do professor e a profissionalidade docente, afirmando que as dimensões profissionais cruzam-se sempre, inevitavelmente, com as dimensões pessoais. Neste sentido, é possível afirmar que existe uma pessoalidade (qualidade da pessoa) e uma profissionalidade (qualidade do(a) profissional), que compõem o sujeito docente.

A seguir, tais diferentes domínios e elementos relativos à profissionalidade docente serão retomados, como parâmetro para análise das representações dos professores acerca de sua competência profissional docente. De modo mais preciso, passamos a apresentar a metodologia adotada para este estudo.

\title{
A abordagem estrutural da Teoria das Representações Sociais: considerações teórico- metodológicas
}

Para atingirmos o objetivo de analisar as representações sociais de professores de matemática brasileiros e franceses acerca de sua competência profissional, tomamos a discussão sobre a Teoria das Representações Sociais (TRS) a partir da abordagem estrutural, ou Teoria do Núcleo Central (TNC), proposta por Abric (1976). De acordo com Abric (2003, p. 59) "uma representação social é um conjunto organizado de informações, de opiniões, atitudes e crenças a propósito de um dado objeto. Socialmente produzida, ela é fortemente marcada pelos valores correspondentes ao sistema sócio-ideológico e à história do grupo". Para Abric (1994a) os elementos constitutivos de uma representação são hierarquizados, afetados de ponderações diferentes, eles mantem entre si relações que determinam a significação e o lugar que ocupam no sistema representacional. 
Todos os elementos de uma representação social não têm a mesma importância. Certos são essenciais, outros importantes, outros, enfim secundários. É importante então, se queremos conhecer, compreender e agir sobre uma representação, pontuar sua organização; isto é a hierarquia dos elementos que a constituem e as relações que estes elementos entretêm entre eles (ABRIC, 2003, p. 59).

A Representação Social, doravante RS, é então compreendida como um sistema sociocognitivo que apresenta uma organização específica: um Sistema Central (ou Núcleo Central - NC) e um Sistema Periférico.

$\mathrm{O}$ NC de uma RS possui três funções essenciais: geradora; organizadora e estabilizadora. Sobre a função geradora do NC, considera-se que "ela é o elemento pelo qual se cria ou se transforma, a significação dos outros elementos constitutivos da representação. É por ela que esses elementos tomam um sentido, um valor" (ABRIC, 1994a, p. 22). Em sua função organizadora: "é o NC que determina a natureza dos laços que unem entre si os elementos da representação. Ele é, neste sentido, o elemento unificador e estabilizador da representação" (idem). Quanto à função estabilizadora, é dito que o NC é constituído pelos elementos que mais vão resistir às mudanças. Sendo assim, Abric (1994b, p. 79) descreve o NC como "estável, coerente, consensual e historicamente marcado". Sem o, ou os elementos do NC, existiria uma total desarticulação da estrutura da representação. A característica de maior resistência às mudanças faz com que possamos conceber que toda modificação no núcleo desencadeia uma transformação na RS. Ainda, podemos afirmar que duas representações são diferentes se estas possuem núcleos diferentes.

Abric e Tafani (1995) destacam que o NC aparece como um conjunto constituído de elementos de natureza e de função diferentes, articulados em torno das dimensões normativas e funcionais e estes são ativados diferentemente segundo o tipo de relação que o grupo considerado entretém com o objeto representado. Isto é, ora certos elementos do núcleo intervêm na formulação de julgamentos e de tomadas de posição, ora intervêm na determinação das práticas sociais ligadas ao objeto. Quanto aos elementos que compõem o NC de uma representação social, segundo a natureza do objeto e a finalidade da situação, Abric e Tafani (1995) os descrevem em três tipos: normativos, funcionais e mistos.

\begin{abstract}
Os elementos normativos, ligados à história coletiva e ao sistema de valores e de normas do grupo social. Estes elementos determinam os julgamentos e as tomadas de posição relativas ao objeto da representação. Eles constituem o quadro de referência a partir do qual este objeto é socialmente avaliado. Os elementos funcionais, ligados à inscrição do objeto nas práticas sociais e /ou operatórias. Estes elementos determinam e organizam as condutas relativas ao objeto. Eles definem notadamente as práticas legítimas quando os indivíduos ou os grupos são confrontados ao objeto da representação. Os elementos mistos que têm a dupla dimensão normativa-funcional e que intervirão tanto na orientação das práticas quanto na produção de julgamentos (ABRIC; TAFANI, 1995, p. 23).
\end{abstract}

Conforme Abric (1994a, p. 23), em situações com uma finalidade operatória: “serão então privilegiados na representação e constituindo o seu núcleo central os elementos mais importantes para a realização da tarefa". Enquanto, "em todas as situações onde intervêm diretamente dimensões socioafetivas, sociais ou ideológicas. Nesse tipo de situações, pode-se pensar que uma norma, um estereótipo, uma atitude fortemente marcada estarão no centro da representação". $\mathrm{Na}$ dimensão normativa são suscetíveis de serem privilegiados julgamentos, estereótipos, opiniões, admitidas pelo sujeito ou grupo. Enquanto que na dimensão funcional o que é preponderante e privilegiado na representação são os elementos diretamente percebidos como pertinentes para eficácia numa ação (ABRIC, 1987). 
Domínios e elementos da profissionalidade docente nas representações sociais de professores...

O Sistema Periférico (SP) é constituído de elementos que podem estar mais ou menos próximos dos elementos do NC. Se eles estão mais próximos, desempenham um papel importante na concretização da significação da representação, se estão mais distantes, podem ilustrar, explicitar ou justificar esta significação. Conforme Sá (2002), os elementos periféricos das RS foram durante algum tempo tomados como circunstanciais e acessórios do NC. Isto é, como se a sua designação "periféricos" já implicasse um certo desdém, algo dispensável, um pano de fundo, algo de menor importância para o estudo das RS. Pelo exposto, convém sublinhar que os elementos periféricos das RS constituem, de fato, a interface entre o NC e a situação concreta na qual se elabora ou funciona a representação e responde a cinco funções essenciais: concretização, regulação, prescrição de comportamentos, proteção e modulações personalizadas.

Para Abric (1994b, p. 79), a primeira função do SP é "a concretização do SC em termos de tomadas de posição ou de condutas"; uma vez que; contrariamente ao SC ele é mais sensível e determinado pelas características do contexto imediato. Assim, é na periferia que a representação se formula em termos concretos, ancorados na realidade, imediatamente compreensíveis e transmissíveis. A função de regulação permite a adaptação da representação às evoluções do contexto, integrando novos elementos ou modificando outros em função das transformações das situações. Os elementos periféricos são prescritores de comportamento, pois eles indicam, com efeito, o que é normal de fazer ou de dizer em uma dada situação, levando em conta a significação e a finalidade da situação. Eles permitem, assim, guiar a ação e as reações dos sujeitos de maneira instantânea.

O sistema periférico assegura a inscrição da representação na realidade concreta e autoriza diversas individualizações desta representação. É por isto que podemos observar indivíduos que têm uma mesma representação (organizada em torno de mesmo núcleo central) tendo, às vezes, práticas sensivelmente diferentes (DESCHAMPS; MOLINER, 2010, p. 126).

O SP, por sua flexibilidade e maleabilidade, permite "a integração nas representações das variações individuais ligadas à história própria do sujeito, a suas experiências pessoais, ao vivido" (ABRIC, 1994b, p. 75). Segundo Arruda (2011, p. 340), "os elementos periféricos, assim, terminam sendo aqueles que dão a cara multifacética da representação, escapando à constância e homogeneidade do núcleo central por carregarem os aspectos mais individuais e mais contingentes, situacionais, da representação".

Particularmente, um estudo sobre as RS baseado na abordagem estrutural implica três tempos sucessivos: o levantamento do conteúdo da representação; o estudo das relações entre os elementos, de sua importância relativa e de sua hierarquia e a determinação e controle do núcleo central (ABRIC, 1994a).

Para o presente estudo, houve a colaboração de 126 professores de matemática brasileiros e 126 professores de matemática franceses, atuantes em escolas públicas no Ensino Fundamental (collége) e no Ensino Médio (lycée). Na primeira etapa de coleta de dados, para o levantamento do conteúdo da representação; os professores responderam a um Teste de Associação Livre de Palavras (TALP) no qual deveriam indicar seis palavras ou expressões que lhes viessem à mente quando pensassem em competência para ensinar matemática - organizar o planejamento do ensino de um tema, preparar uma aula e trabalhar em sala de aula. Desta forma, levando-se em conta o trabalho docente dentro e fora da sala de aula.

Na segunda etapa, para levantamento da hierarquia dos elementos das representações, os professores, dentre as suas seis indicações, escolheram aquelas duas consideradas, por eles, como as mais importantes. Na terceira etapa, para a determinação e controle do NC, 30 professores brasileiros e 10 professores franceses foram solicitados a classificar no conjunto dos elementos 
considerados como os mais importantes quais seriam: totalmente indispensáveis; indispensáveis; dispensáveis ou totalmente dispensáveis e justificar suas respostas por meio de entrevista.

Quanto ao processo de análise dos dados, realizamos a codificação das características dos sujeitos e inserção do que foi dito por cada um deles no software Trideux ${ }^{7}$, que nos auxiliou na frequência do que foi mencionado pelos professores. Ressaltamos que o padrão estatístico utilizado por este software é a frequência igual ou maior que 4 indicações. Posteriormente, realizamos uma análise de conteúdo do material coletado baseada em Bardin (1997): primeira leitura do corpus; segunda leitura para pré-categorização; terceira leitura para construção de grades de categorias contendo tema geral, palavras e frases relacionadas a esse tema; contagem da frequência final dos elementos nas categorias e subcategorias.

Como parâmetro de análise para categorização dos elementos das RS, retomamos o quadro teórico; ou seja, o que identificamos sobre a composição da profissionalidade docente (no limite dos autores consultados); como podemos ver no quadro a seguir:

Quadro 1- Domínios e elementos relativos à profissionalidade docente

\begin{tabular}{|c|c|}
\hline Domínios & Elementos da profissionalidade docente \\
\hline $\begin{array}{l}\text { Domínio do } \\
\text { sistema } \\
\text { educativo }\end{array}$ & $\begin{array}{l}\text { Conhecimentos relativos ao sistema educativo (política educativa nacional, estrutura e } \\
\text { funcionamento da instituição, compreensão da dinâmica dos projetos do } \\
\text { estabelecimento, etc.). (BANCEL, 1989). O contexto político que se refere às } \\
\text { determinações das políticas públicas, as legislações e seus efeitos (BAZZO, 2007). }\end{array}$ \\
\hline $\begin{array}{l}\text { Domínio da } \\
\text { formação } \\
\text { profissional }\end{array}$ & $\begin{array}{l}\text { Uma formação universitária longa e mais frequentemente, de natureza científica... } \\
\text { (MELYANI, 1995). Compromisso de atualização e aperfeiçoamento dos } \\
\text { conhecimentos e habilidades que lhes são próprios (SARRAMONA, 1995). }\end{array}$ \\
\hline $\begin{array}{c}\text { Domínio da } \\
\text { sociabilidade } \\
\text { profissional }\end{array}$ & $\begin{array}{l}\text { Competências organizacionais - relacionadas com as metodologias do trabalho } \\
\text { coletivo, de organização de um grupo profissional local; de estímulo à comunicação } \\
\text { interna e externa, de incentivo as suas relações com o meio e competências } \\
\text { dramáticas e relacionais (DEMAILLY, 1992). Um certo direito social como indivíduo } \\
\text { e como coletivo profissional (SARRAMONA,1995). A pertença a um corpo coletivo } \\
\text { (ROLDÃO, 2005). }\end{array}$ \\
\hline $\begin{array}{c}\text { Domínio } \\
\text { deontológico }\end{array}$ & $\begin{array}{l}\text { O sistema de valores e normas próprias aos professores, que constituem o universo } \\
\text { «moral » deste grupo profissional (MELYANI, 1995). Compromisso deontológico } \\
\text { com a prática docente (SARRAMONA, 1995). O ensino supõe um compromisso de } \\
\text { caráter moral (CONTRERAS, 2002). Competência ética - [...] O papel essencial da } \\
\text { orientação ética e sociopolítica do professor na produção da prestação de serviço } \\
\text { (DEMAILLY, 1992). O poder de decisão sobre a ação desenvolvida e consequente } \\
\text { responsabilização social e pública pela mesma (ROLDÃO, 2005). }\end{array}$ \\
\hline $\begin{array}{l}\text { Domínio } \\
\text { disciplinar }\end{array}$ & $\begin{array}{l}\text { O saber específico indispensável ao desenvolvimento da atividade e sua natureza } \\
\text { (ROLDÃO, 2005). Delimitação de um âmbito específico de atuação } \\
\text { (SARRAMONA, 1995). A delimitação de um objeto (ABAELLA, 1992; BRAEM, } \\
\text { 2000). } \\
\text { Conhecimentos relativos à identidade disciplinar (BANCEL, 1989). Conhecer aqueles } \\
\text { aspectos da cultura e do conhecimento que constituem o âmbito ou o objeto do que } \\
\text { se ensina (CONTRERAS, 2002). }\end{array}$ \\
\hline
\end{tabular}

\footnotetext{
${ }^{7}$ Ver: http://cibois.pagesperso-orange.fr/Trideux.html.
} 
Domínios e elementos da profissionalidade docente nas representações sociais de professores...

\begin{tabular}{|c|c|}
\hline $\begin{array}{c}\text { Domínio } \\
\text { pedagógico }\end{array}$ & $\begin{array}{l}\text { Conhecimentos relativos à gestão das aprendizagens (pedagógicos) (BANCEL, 1989). } \\
\text { O contexto pedagógico caracterizado pelas práticas pedagógicas cotidianas que } \\
\text { derivam do ensinar como, as rotinas da classe, os procedimentos de ensino, os } \\
\text { processos de avaliação, o material escolar, etc. (BAZZO, 2007). Saber e saber-fazer } \\
\text { pedagógicos - relacionados à questão do trabalho em grupo na sala de aula: } \\
\text { organização espaço - temporal [...], conhecimento das características dos diversos } \\
\text { tipos de grupos e capacidade para operacionalizá-las [...] (DEMAILLY, 1992). }\end{array}$ \\
\hline $\begin{array}{l}\text { Domínio } \\
\text { didático }\end{array}$ & $\begin{array}{l}\text { Conhecimentos relativos à gestão das aprendizagens (didáticos) (BANCEL, 1989). } \\
\text { Saberes didáticos relacionados à transmissão e aquisição de um domínio de saber } \\
\text { escolar (DEMAILLY, 1992). Um certo domínio de habilidades, técnicas e, em geral, } \\
\text { recursos para a ação didática [...] (CONTRERAS, 2002). }\end{array}$ \\
\hline $\begin{array}{l}\text { Domínio da } \\
\text { pessoalidade }\end{array}$ & Qualidades da pessoa do professor e do profissional professor (NÓVOA, 2009). \\
\hline
\end{tabular}

Fonte: autoria própria.

Os diferentes domínios e elementos relativos à profissionalidade docente (Quadro 1) foram então contrastados com as RS dos professores de matemática brasileiros e franceses acerca de sua competência profissional docente, de modo a identificarmos as semelhanças e diferenças entre as RS destes dois grupos.

\section{As representações sociais dos professores de matemática acerca de sua competência profissional}

Dentre as RS dos professores do Brasil e da França, os elementos principais do NC, levando-se em conta aqueles que foram hierarquizados como os mais importantes e logo depois os considerados como totalmente indispensáveis para todos os estímulos indutores (competência para: ensinar, organizar o planejamento, preparar aula e trabalhar em sala de aula) foram: "conhecimento matemático e capacidade de dominá-lo", relacionados ao dominio disciplinar.

Figura 1 - NC das RS dos professores brasileiros

Figura 2- NC das RS dos professores franceses
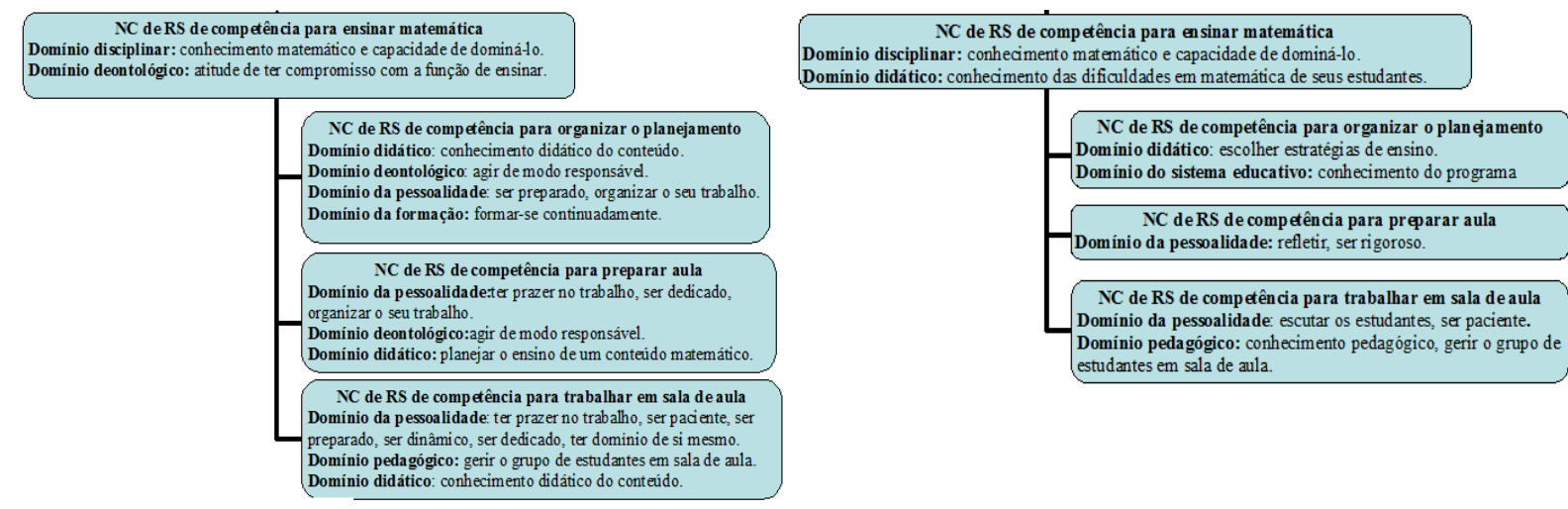

Fonte: autoria própria. 
De acordo com Abric (2002, p. 86), “os elementos do núcleo central são suscetíveis de serem ativados diferentemente segundo o contexto social". De tal forma que, adjuntos aos elementos principais do NC (conhecimento matemático e capacidade de dominá-lo) (Figura 1), foi identificada, no caso dos professores brasileiros, a "atitude de ter compromisso com a função de ensinar" (domínio deontológico) e no caso dos professores franceses (Figura 2), o conhecimento das dificuldades em matemática de seus estudantes (domínio didático).

Sublinhamos que os elementos centrais podem ser ativados diferentemente em função do grupo social concernente, mas também em função da finalidade da situação na qual a representação é utilizada (ABRIC; TAFANI, 1995). Assim, nas RS da competência para organizar o planejamento de ensino de um tema, o sentido atribuído pelos professores brasileiros ao conhecimento matemático e à capacidade de dominá-lo (Figura 1) se manifestou quanto a assegurar melhores resultados na aprendizagem dos estudantes. Por ex.: "Em minha opinião o conhecimento matemático é essencial e acredito que hoje um dos motivos dos baixos resultados dos estudantes em matemática é a dificuldade que o professor tem com relação ao conhecimento do conteúdo matemático" (Profa. EFBR16).

Outro aspecto de realce, diz respeito à aproximação do conhecimento matemático com o conhecimento didático, sobretudo, para a construção de sequências didáticas no momento do planejamento do ensino de um conteúdo. Foi dito: "Eu acho que dentro do planejamento, é importantíssimo que o professor visualize a junção do conbecimento matemático com o didático... Buscar ou visualizar didaticamente, o que você deve trabalhar e como deve trabalhar" (Prof ${ }^{a}$. EF-BR04). O compromisso com a função de ensinar (dominio deontológico) foi apresentado frente às dificuldades de atuação na profissão docente. "Compromisso? Eh! Ser professor atualmente não é muito fácil. A gente tem visto na mídia muitos aspectos negativos com relação à profissão professor" (Prof ${ }^{\circ}$. EFM-BR05). Também identificamos sentidos atribuídos às palavras responsabilidade ou compromisso nas RS de competência para organizar o planejamento, exemplificadas no contexto de outras profissões (médicos e engenheiros): "Qualquer profissão que eu siga, que eu exerça, tenho que ter responsabilidade. Um médico tem que ter responsabilidade com a vida do sujeito, um professor, ele tem essa mesma responsabilidade, e talvez até maior" (Prof ${ }^{a}$. EF-BR15).

A capacidade de organizar seu trabalho pessoal se apresentou bem relacionada ao professor "ser preparado" (domínio da pessoalidade). "Eu sou de uma geração, enquanto estudante, de que os professores de matemática eram desorganizados. Ai nesse caso é o professor que entra na sala de aula sem um preparo adequado" (Prof ${ }^{\mathrm{a}}$. EF-BR14). Tais colocações se coadunaram com a importância da formação inicial e continuada (dominio da formação profissional): "Um professor não sai preparado da faculdade. A gente passa quatro, cinco anos lá, aprendendo as didáticas, tudo aquilo, toda a psicologia, toda a matemática, mas ele não sai preparado. A gente tem que estar sempre aprendendo coisas novas" (Prof ${ }^{a}$. EFBR07).

Quanto as RS dos professores franceses (Figura 2) o conhecimento matemático e a capacidade de dominá-lo (domínio disciplinar) foram mencionados em torno das ideias utilizadas para a organização do planejamento decorrentes da experiência no ensino de um determinado conteúdo: "Se é um tema que eu já trabalhei em anos precedentes, vou ter mais ideias sobre o que se passa quando ensinamos este assunto, vou talvez. me direcionar, em particular, em relação ao que se passou bem ou se passou mal no último ano" (Prof ${ }^{a}$. EM-FR03). O conhecimento das dificuldades em matemática dos estudantes (domínio didático) foi apontado como um meio de organizar o planejamento de modo mais rápido. Também foi ressaltada a capacidade de o professor adaptar-se ao público ao qual ele ensina. 
Domínios e elementos da profissionalidade docente nas representações sociais de professores...

Faz tempo que eu ensino e de fato, no início deste ano, eu tinha passado bastante tempo a construir meu curso, olhando tudo e depois, eu organizei um capitulo inteiro e depois a cada aula, ao final, en refaz̧ia, porque eu via que não funcionava em relação aos estudantes e agora, como eu já conbeço melhor os estudantes, este trabalho é mais rápido, porque eu percebo quais devem ser as dificuldades deles, em que vão ficar bloqueados, etc. (Prof ${ }^{\circ}$. EF-FR04).

Sobre o conhecimento do programa curricular (dominio do sistema educativo), os professores franceses afirmaram:

\footnotetext{
Aqui, é a lei, não podemos ensinar fora do programa. Podemos ensinar coisas mais do que o programa, mas não temos o direito de exigi-las aos estudantes, de questionar os estudantes sobre estas (Prof ${ }^{\circ}$. EM-FR01).

Em primeiro, somos obrigados a nosso papel de funcionário, temos a obrigação de conhecer os programas. Não pode ser de outra maneira (Profa. EF-FR04).
}

Pelo exposto, sobre as RS de competência para organizar o planejamento, destacaram-se, de modo particular, entre os professores brasileiros, elementos relativos aos domínios da pessoalidade docente (ex: ser preparado, ser organizado), deontológico (ex: agir responsavelmente frente aos aspectos negativos da profissão docente) e da formação profissional (ex: buscar se atualizar profissionalmente). Enquanto entre os professores franceses, destacamos uma ênfase particular sobre o elemento do domínio do sistema educativo (ex: conhecer os documentos curriculares oficiais).

Nas representações de competência para preparar uma aula de matemática, entre os professores brasileiros (Figura 1), os sentidos atribuídos ao conhecimento matemático e à capacidade de dominá-lo (domínio disciplinar) se sobressaíram como uma necessidade à compreensão do processo de ensino e de aprendizagem.

O professor tem que ter um conhecimento bom para poder ter argumentos junto aos estudantes, ele poder entender quem está em um nivel mais avançado ou médio. Isto não é ter conbecimento para saber resolver questões, mas en saber de onde e como começa o processo de aprendizagem daquele conceito (Profa. EF-BR15).

No dominio da pessoalidade, os elementos "ter prazer no trabalho, ser dedicado e organizar o seu trabalho" apresentaram uma forte relação com o compromisso com a função de ensinar, o agir de modo responsável (domínio deontológico). "Se eu não tiver praz̧er, eu vou achar que o que en fizer, de qualquer jeito, vai estar bom. Então, no momento que eu tenho prazer, eu vou ter mais ânimo para preparar uma boa aula para meus estudantes" (Prof ${ }^{a}$. EFM-BR12). Enquanto para os professores franceses, o papel do conhecimento matemático no momento da preparação da aula é apontado como um prérequisito importante, foi dito: "Dominar o saber matemático, para mim, significa que quando estamos dentro da sala de aula, pode parecer estranho o que vou dizer: é tarde. Porque quando estamos sozinhos preparando as aulas, eu creio que é quando precisamos ter conhecimento matemático" (Profa. EM-FR2). Tal colocação se coadunou com a capacidade de refletir e ser rigoroso (domínio da pessoalidade):

É necessário ser rigoroso porque eles misturam as noções, aquelas que lhes parecem um pouco similares [...]. Logo, ter rigor para tudo, sobre o que escrevemos e sobre tudo o que dizemos. Se nós, de nossa parte, não formos rigorosos, não poderemos pedir aos estudantes que eles sejam; logo, isto é realmente essencial (Prof ${ }^{\mathrm{a}}$. EM-FR7).

Passo muito tempo a me questionar durante a preparação, refletindo a: em que ordem eu vou poder fazer isto ou aquilo? Qual atividade devo escolher? Como os estudantes vão reagir? E mesmo em relação ao já construído (Profa. EM-FR3).

Destarte, sobre as representações de competência para preparar uma aula de matemática, identificamos entre os professores brasileiros no dominio da pessoalidade uma ênfase sobre uma dimensão afetiva (ex.: ser dedicado, ter prazer no fazer); enquanto, entre os professores franceses,

Práxis Educativa, Ponta Grossa, v. 12, n. 3, p. 887-908, set./dez. 2017 Disponível em: <http://www.revistas2.uepg.br/index.php/praxiseducativa> 
a ênfase sobre os elementos do domínio da pessoalidade foram mais no sentido do zelo ao saber matemático, da mensura das consequências das atividades propostas aos alunos; respectivamente relacionados aos elementos "rigor" e "reflexão".

Sobre as representações de competência para trabalhar em sala de aula (Figura 1), entre os professores brasileiros, o conhecimento matemático e a capacidade de dominá-lo (domínio disciplinar) adquiriu a conotação de "condição para ser respeitado em sala de aula". Foi dito: "O professor de matemática, então, se ele não tem esse conbecimento matemático, acredito que já vai se dificultar em sala de aula. Se ele falha numa questão, se ele está dando uma aula, se ele erra alguma coisa, ele já é logo observado em relação a isso" (Prof ${ }^{a}$. do EM-BR10). Por sua vez, o compromisso com a função de ensinar (dominio deontológico) se coadunou com os elementos do domínio da pessoalidade: prazer no trabalho, ser paciente, ser preparado, ser dedicado, ter domínio de si mesmo. Tal fato ocorreu em maior parte pelas "queixas" dos professores sobre a falta de interesse dos estudantes em matemática, pelos problemas de indisciplina e pelo desejo de os estudantes obterem um "bom futuro profissional".

É assim, às vežes, a gente fica dizendo: - Minha gente: para tudo vocês precisam de matemática. Para concurso, para vestibular, para um trabalho que vocês vão ter, que não seja concurso, trabalhar numa farmácia, trabalhar numa fábrica, em todo lugar vocês precisam de matemática (Profa . EF-BR9).

A responsabilidade do professor dentro da sala de aula é triplicada. Porque você tem que ser pai, mãe, pedagogo, psicólogo, amigo, então a responsabilidade é muito grande (Profa . EF-BR20).

Outros elementos de destaque foram a relação entre o professor ser dinâmico (domínio da pessoalidade) e a capacidade gerir o grupo de estudantes (dominio pedagógico). "O professor tem que ter aquele jogo de cintura para poder gerir a classe dentro da sua aula. Ele tem que conbecer onde ele está pisando porque existem vários tipos de grupos de estudantes" (Profa. EM-BR10).

No caso dos professores franceses (Figura 2) o conhecimento matemático e a capacidade de dominá-lo (dominio disciplinar) se apresentaram em estreita relação com a capacidade de gerir o grupo de estudantes (dominio pedagógico). "Um bom professor de matemática pode não saber gerir sua classe e inversamente, conseguir gerir a classe sem necessariamente ensinar bem... Então, os dois estão ligados... Podemos ser bem competentes no ensino e ter dificuldade de autoridade" (Prof ${ }^{\mathrm{D}}$. EF-FR9). Outro aspecto diz respeito ao professor ter clareza em suas explicações (domínio da pessoalidade). Um professor afirmou: "Precisamos fazế-los compreender porque estudamos isto ou aquilo; qual o objetivo, o que está por trás, o que queremos que eles retenham... Eles veem frequentemente o que ensinamos como não sei o quê" (Prof ${ }^{\circ}$. EF-FR9).

No depoimento da professora francesa: "Estar atento às dificuldades de aprendizagem dos estudantes caminha junto com escutar os estudantes [...]. Então, eu sei que em uma hora certos estudantes não conseguem fazer algo. Ai, eu posso dar atenção a esta dificuldade, a esta demanda de trabalhar sobre isto" (Profa. EM-FR3). O conhecimento das dificuldades dos estudantes em matemática (domínio didático) se concatenou à capacidade do professor escutar os estudantes (domínio da pessoalidade), também no sentido de o professor prever momentos de escuta entre os estudantes e com o professor. "Para dar aula, en penso que é preciso ter um espirito relativamente aberto, de tentar estabelecer um debate entre os estudantes, que eles façam trocas entre eles e comigo" (Profo. EF-FR9). E, de outra forma, no sentido relacionado à confiança dos estudantes de serem escutados pelo professor: "O estudante pode dizer: - Eu posso pedir ajuda, ela me escuta; en posso investir mais, sabendo que terá uma resposta; mesmo que, não tenha no mesmo instante" (Prof ${ }^{a}$. EF-FR10).

Podemos dizer sobre as representações de competência para trabalhar em sala de aula, que foi destaque entre os professores brasileiros gerir o grupo de estudantes (domínio pedagógico) em face aos conflitos dentro da sala (de ordem pessoal, social, etc.) de modo a possibilitar, por meio do ensino de matemática, um futuro melhor para eles: conseguir um emprego, passar no

Práxis Educativa, Ponta Grossa, v. 12, n. 3, p. 887-908, set./dez. 2017 Disponível em: <http://www.revistas2.uepg.br/index.php/praxiseducativa> 
Domínios e elementos da profissionalidade docente nas representações sociais de professores...

vestibular (elementos ligados ao compromisso docente - domínio deontológico). Enquanto, entre os professores franceses, foi mais recorrente a "capacidade de escutar os estudantes", no sentido de estar atento as suas dificuldades em matemática, visando superá-las. Contudo, sem uma finalidade aparente de lhes assegurar uma ascensão social como colocada pelos professores de matemática brasileiros.

\section{Considerações finais}

Colocamos a presente perspectiva de investigação da profissionalidade docente, baseada nas RS, engendradas no contexto social e profissional dos professores do Brasil e da França, levando-se em conta que a noção de RS considera ao mesmo tempo, a atividade do sujeito sobre o mundo e, reciprocamente, da ação do meio, empírico e social, sobre o indivíduo. Como vimos os elementos principais do NC das RS de competência para ensinar matemática foram: "conhecimento matemático e capacidade de dominá-lo" (dominio disciplinar) e os seus elementos adjuntos, no caso dos professores brasileiros " ter compromisso com a função de ensinar » (domínio deontológico) e no da França " conhecimento das dificuldades em matemática dos estudantes» (dominio didático). Estes elementos serviram, em linhas gerais, de norte para analisarmos o campo semântico das RS em tela (TALP- teste de hierarquização) e a atribuição de significados a estes (entrevistas). Visto que "é essencial, então, depois de ter pontuado os elementos do núcleo, tentar definir os fatores de sua ativação" (ABRIC, 2002, p. 87). Sobremaneira, consideramos a ativação de tais elementos, em função das representações de competência para: organizar o planejamento; preparar aula e trabalhar em sala de aula, pondo em relevo o princípio que no NC: «alguns elementos vão ser mais utilizados, mais solicitados que outros para definir a significação do objeto ou das práticas que lhes são associadas » (idem).

Dentre todos os domínios da profissionalidade docente analisados, se por um lado o "disciplinar" foi o que mais se sobressaiu, não encontramos referência a elementos do domínio da sociabilidade profissional entre as RS docentes. Este último, relacionado a atividades profissionais desenvolvidas coletivamente entre seus pares. Este fato, como outros, resta-nos em aberto. Até onde conseguimos desenvolver o presente estudo, esperamos ter contribuído para o empreendimento de novas pesquisas que busquem melhor compreender a profissionalidade docente a partir de seus diversos domínios (disciplinar, pedagógico, didático, entre outros). Bem como, o desvelamento da noção de competência profissional docente, na medida em que os diferentes tipos de conhecimentos, capacidades, atitudes, afeições e/ou motivações, qualidades subjetivas e/ou traços da personalidade, expressos pelos professores investigados, revelam a sua multidimensionalidade (cognitiva, ético-política, afetiva, entre outras). Dimensões estas, advindas da própria percepção dos professores sobre o trabalho docente. O que corrobora a afirmação que as RS devem ser estudadas articulando "os elementos afetivos, mentais e sociais e integrando - ao lado da cognição, da linguagem e da comunicação - a consideração das relações sociais que afetam as representações e a realidade material, social e ideativa sobre a qual elas têm de intervir" (JODELET, 2001, p. 75).

Por fim, ressaltamos o papel do contexto social, na medida em que podemos identificar diferenças significativas nas representações dos professores de matemática, das escolas públicas brasileiras e francesas (EF e EM). O que nos leva a crer que outros elementos possam ser levantados, em outros cenários, no ensino de outras áreas e de outros contextos escolares. 


\section{Referências}

ABALLEA, F. Sur la notion de professionnalité. Recherche Sociale, Paris, n. 124, p. 39-49, 1992.

ABBOTT, A. The system of professions: an essay on the division of expert labor. Chicago: The University of Chicago Press, 1988.

ABRIC, J. C. Cooperation, compétition et représentation sociale. Del Val: Cousset, 1987.

ABRIC, J. C. Jeux, conflits et répresentations sociales. Thèse Etat, Aix-en-provence: Université de Provence, 1976.

ABRIC, J. C. L'appoche structurale des représentations sociales: développements récents. Psychologie \& Société, Toulouse, v. 2, n. 4, p. 81-103, 2002.

ABRIC, J. C. Pratiques sociales et représentations. Paris: Puf, 1994a.

ABRIC, J. C. L'organisation interne des representations sociales: système central et système périphérique. In: GUIMELLI, C. Structures et transformations des représentations sociales. Neuchâtel: Delachaux et Niestlé,1994b.

ABRIC, J. C. Méthodes d'étude des représentations sociales. Ramonville Saint-Agne: Éditions Érès, 2003.

ABRIC, J. C.;TAFANI, E. Nature et fontionnement du noyau central d'une représentation sociale : la représentation de l'entreprise. Les Cahiers Internationaux de Psychologie Sociale, Paris, n. 28, p. 22-31, dez. 1995.

ALMEIDA, A. J. Contributos da Sociologia para a compreensão dos processos de profissionalização. Medi@ções, Setúbal, v. 1, n. 2, p. 115-127, 2010.

AMBROSETTI, N.; ALMEIDA, P. A constituição da profissionalidade docente: tornar-se professora de educação infantil. In: REUNIÃO ANUAL DA ANPED, 30., 2007, Caxambu. Anais... Caxambu: Anped, 2007, p. 1-16.

ARRUDA, A. Representações sociais: dinâmicas e redes. In: ALMEIDA, A.; SANTOS, M.; TRINDADE, Z. Teoria das Representações Sociais: 50 anos. Brasilia: Technopolitik, 2011.

BANCEL, D. Créer une nouvelle dynamique de la formation des maîtres: rapport. Paris: Ministère de l'Education Nationale, 1989.

BARBOSA, M. L.O. Reconstruindo as minas e planejando as gerais: os engenheiros e a constituição dos grupos sociais. 1993. 293 f. Tese (Doutorado em Sociologia) - Instituto de Filosofia e Ciências Humanas, Universidade Estadual de Campinas, Campinas, 1993.

BARDIN, L. Análise de conteúdo. Lisboa: Edições 70, 1997.

BARISI, G. La notion de professionalitá pour les syndicats em Italie, l'emploi. Coloque de Dourdan. Paris: Máspero, 1982. p. 379-394. 
Domínios e elementos da profissionalidade docente nas representações sociais de professores...

BAZZO, V. L. Constituição da profissionalidade docente na Educação Superior: desafios e possibilidades. 2007. 269 f. Tese (Doutorado em Educação) - Faculdade de Educação, UFRGS, Porto Alegre, 2007.

BECKER, H. Les mondes de l'art. Paris:Flamarion, 1988.

BLIN, J-F. Représentations, pratiques et identités professionnelles. Paris: L'Harmattan, 1997.

BRAEM, S. Le nécessaire développement théorique de la notion de professionnalité pour la sociologie des professions française. Interim Conference of ISA Research Committee Sociology of professional groups RC52, Lisboa, 2000.

BRAEM, S.; ABALLEA, F. La notion de professionnalité: un concept «transfert ». Recherche Sociale, Paris, n. 163, jul./set. 2002.

BUCHER, R.; STRAUSS, A. Profession in process. In: STRAUSS, A. La trame de la négociation. Paris: L'Harmattan, 1992.

CHAMPY, F. La sociologie des professions. Paris: Puf, 2009.

CONTRERAS, J. A autonomia de professores. São Paulo: Cortez, 2002.

CRUZ, S. P. S.; NETO, J. B. Discutindo os elementos estruturantes da profissionalidade polivalente na docência nos anos iniciais do ensino fundamental. In: REUNIÃO ANUAL DA ANPED, 35, 2012, Porto de Galinhas, Anais... Porto de Galinhas: Anped, 2012, p. 1-16.

D'AVILA, C. A constituição da profissionalidade docente em cursos de licenciatura. In: REUNIÃO ANUAL DA ANPED, 33., 2010, Caxambu, Anais... Caxambu: Anped, 2010, p. 1 16.

DADOY, M. À la recherche de la notion de professionnalité. Paris: Cahier du Plan Construction, 1986.

DEMAILLY, L. Modelos de formação contínua e estratégia de mudança. In: NOVOA, A. (Coord.). Os professores e sua formação. Lisboa: Dom Quixote,1992.

DEMAZIÈRE, D.; GADÉA, C. Sociologie des groupes professionnels: acquis récentes et nouveaux défis. Paris: La Découverte, 2009.

DESCHAMPS, J. C ; MOLINER, P. L’identité en psychologie sociale: des processus identitaires aux représentations sociales. Paris: Armand Colin, 2010.

DUBAR, C. A socialização: construção das identidades sociais e profissionais. São Paulo: Martins Fontes, 2005.

DUBAR, C.; TRIPIER, P. Sociologie des professions. 2. ed. Paris: Armand Colin, 2010.

DURKHEIM, E. Émili Durkheim: sociologia. 3. ed. São Paulo: Ática, 1984. 
FREIDSON, E. Renascimento do profissionalismo: teoria, profecia e política. São Paulo: Edusp, 1998.

GOODE, W.J. Community within community: the professions. American Sociological Review, v. 22, n. 2, p. 195-200, 1957.

HUGHES, E. Men and their work. Glencoe: The Free Press, 1958.

JODELET, D. Representações sociais um domínio em expansão. In: JODELET, D. As representações sociais. Rio de Janeiro: EDUERJ, 2001.

LUCAS, Y. Qu'est-ce qu'une sociologie des groupes professionnels? In: LUCAS, Y.; DUBAR, C. Genèse et dynamique des groupes professionnels. Paris: Presses Universitaires de Lille, 1994.

MASSIP, C. Évolution des publics en alternance et de la professionnalité du formateur. Paris: L'Harmattan, 2000.

MELYANI, M. Professionnalisation anodine ou clé de voûte du métier enseignant. Revue des Sciences de l'Education, Montreal, v. 21, n. 3, p. 519-539, 1995. DOI : 10.7202/031809ar

NÓVOA, A. (Org.). Profissão professor. Porto: Porto Editora, 1999.

NÓVOA, A. Professores: imagens do futuro presente. Lisboa: EDUCA, 2009.

PARSON, T. The Case of Modern Medical Practice. In: Essays in sociological theory. Glencoe: The Free Press, 1958. p. 34-50.

RAMALHO et al. Formar o professor profissional: perspectivas e desafios. 2.ed. Porto Alegre: Sulina, 2004.

ROLDÃO, M. Profissionalidade docente em análise: especificidades do ensino superior e não superior. Nuances, São Paulo, v. 11, n. 12, p. 105-126, jan./dez. 2005.

SÁ, C. Núcleo central das representações sociais. 2. ed. Petrópolis: Vozes, 2002.

SACRISTÁN, G. Consciência e ação sobre a prática como libertação profissional dos professores. In: NÓVOA, A. (Org.). Profissão professor. Porto: Porto Editora, 1999.

SARRAMONA, J. La professionalitat pedagógica, en L'educació: el repte del tercer mileni. In: SIMPOSIO INTERNATIONAL, 1995, Barcelona, Atas... Barcelona: Institució Familiar d'Educació. 1995. p. 7-12.

TARDIF, M. et al. Organisation bureaucratique, travail scolaire et professionnalisation de l'enseignement. In: BOURDONCLE, R.; DEMAILLY, L. Les professions de l'éducation et de la formation. Paris: PUS, 1998.

VEIGA, I. P. Profissionalização docente. In: COLÓQUIO FORMAÇÃO DE EDUCADORES, 2., 2006, Salvador, Anais... Salvador: UNEB, 2006, p. 15-17. 
Domínios e elementos da profissionalidade docente nas representações sociais de professores...

WILENSKY, H. The professionalization of everyone? American Journal of Sociology, Chicago, n.2, p. 137-158, 1964.

Recebido em 09/08/2016

Versão corrigida recebida em 16/06/2017

Aceito em 20/06/2017

Publicação online em 27/07/2017 